\title{
Behaviour of Compressed Stabilised Earth Block Masonry under Compressive Loading
}

\author{
TV Srinivas Murthy, Krishnamurthy Pandurangan
}

\begin{abstract}
Today, there is a necessity to build structures which are economical and last for long. The buildings constructed with earth substance without stabilization, deteriorate quickly in bad weather. Compressed stabilized earth block (CSEB) is an alternative building block among the Engineered brick products. These are non pollution, eco-friendly and the construction tends towards green building. Stress-Strain characteristics and mechanical properties are required for effective and economical design. These values vary due to percentage difference in the ingredients in soil at different locations. Here, the structural properties of stabilized block masonry in cement mortar 1:3 and 1:5 are evaluated under compressive load in vertical direction. $f_{b}$ of CSEB is $9.587 \mathrm{MPa}$, $E: 1550$ MPa and $\mu: 0.242$.
\end{abstract}

Index Terms - CSEB, Brick masonry, Mortars, $f_{b}, \sigma-\varepsilon$ relation, Modulus of Elasticity.

\section{INTRODUCTION}

Soil is an essential material required in conventional buildings. The earth buildings without stabilization, suffer from strength, water resistance and durability. The buildings deteriorate rapidly with severe weather conditions. There is burning demand of durable houses which could accommodate population over growth. Today, many types of bricks are manufactured and one of them is CSEB. This has the benefit of consuming the local material available at sight. The dug up foundation soil if suitable, can be consumed for manufacturing blocks at sight and utilized in building construction. To overcome the previous deteriorating problems, soil stabilization is adopted for improving resilience. Manufacturing process in CSEB consumes less energy and carbon emission is negligible. CSEB consumes around $10 \%$ of energy w.r.t conventional and concrete brick [1. Fetra Riza Venny, Abdul Rehman and Ahmad Zaidi].

Soil basically consists of four basic ingredients: clay, silt, sand and gravels. At each sight the proportion in soil varies. Quality soil consists of gravel 15\%, sand 50\%, silt $15 \%$ and clay $20 \%$. A sandy soil is good for CSEB than clayey soils [2 Satprem Auroville Earth Institute]. Lime when mixed in clayey soil, absorbs water, stabilizes and decreases flexibility [1 Fetra Venary Riza, Ismail Abdul Rehman ].

\section{A. Soil stabilization}

Soil stabilization is a process which improves the existing soil condition such as strength, decreases in porosity and improves in water proofing. There are three methods to make

TV Srinivas Murthy, Civil Engineering Dept. Pondicherry Engineering College, Puducherry, 605014, India. Ph: 9385323784

Krishnamurthy Pandurangan, Civil Engineering Dept. Pondicherry Engineering College, Puducherry, 605014, India. the soil stable, i.e. i) chemical ii) mechanical and iii) physical In mechanical stabilization, soil property is improved by compaction, vibration and thereby soil density is enhanced and decrease in pores takes place. In chemical stabilization, reaction is achieved between ingredients in soil and cementing material to perk up the soil condition. Some of the chemical stabilizers to name: Ash from thermal station, lime and cement [3 Bachir and Abdel Hamid Guettala].

\section{B. Strength}

Among many developed processes, CSEB is one of alternatives. Soil having more sand, cement stabilizes better. Lime as a stabilizer is suitable for clayey soils. It's strength increases in long term [2 Auroville Earth Institute, 4 Guettala, Houari, Mezghiche and Chebili]. Modern researchers found that CSEB not only minimizes the size, shrinkage cracks, but also enhanced the durability and tensile strength [5 Ziegler, Ling and Perry]. Soil mixed with alkali treated palm fibers increased the compressive strength with lime content 8-10\%. However further increase in quantity decreases in strength [3 Bachir Tallah].

\section{Thermal conductivity}

Low thermal conductivity retains heat in cooler circumstances and cools during heat in the building [6 Bahar R. Benazzoug M and Kenai. S]. Heat resistance increases with cement $4 \%$ mixed with $2 \%$ saw dust and makes it lighter also. However the addition reduces the compression strength and Elasticity to some extent [7 Ntamack, Degho, and Beda].

\section{Water Absorption (WA)}

Strength and durability of stabilized block depends on water absorption and also the content of clay and cement. When the WA is high, there is swelling in the soil and strength reduction takes place. Due to increase in clay content, WA and porosity both increase [8 Walker P., Stace T.].

\section{E. Moisture content}

Moisture content effects strength and durability at time of construction. Dry brick absorbs water rapidly from mortar and prevents good adhesion. In case of very wet brick, mortar tends to float without proper adhesion [9 Oti J.E., Kinuthai J.M., Bai J., 10 Walker P. ].

\section{F. Durability}

CSEB mixed with cement, lime and GGBS improves the durability in temperature variation [9 Oti]. With lower clay content and partial increase in cement content durability improves. When the clay content exceeds $20 \%$, durability deteriorates [11 Walker P. J.]. 


\section{G. Types of mortars}

Mortar consists of sand, cement and other inert materials mixed with water. These are used for joining the masonry units. Afore mentioned materials are for CSEB, which are of different types namely, Cement mortar, Soil-Cement-sand mortar, Lime-Soil mortar and Cement-Lime-Soil mortar [12 Nanjunda Roa].

\section{H. Mechanical strength of CSEB}

$f_{b}, \mathrm{E}$ and $\mu$ are some of the values used by designers. Varying the quantity of cement and other materials, controls the strength of the blocks.

$$
\begin{aligned}
& \text { Compressive strength }(\mathrm{MPa})=-0.75+0.3 \times \mathrm{A} \times \mathrm{B}^{2} \\
& \text { where } \mathrm{A}=\text { cement content }(\%) / 10 \% ; \mathrm{B}=\text { Density }\left(\mathrm{Kg} / \mathrm{m}^{3}\right) \\
& / 1700[13 \text { Heathcote } \mathrm{Keven}] . \\
& \text { Cement content used in strength determination is based on } \\
& \text { an effective cement content as determined by: }
\end{aligned}
$$

Effective Cement Content $\%=$ Cement Content $\%$ - 3xClay Content \%

For example a $50 \%$ clay soil stabilized with $5 \%$ cement would give an effective cement content of: $5-(3 \times 0.5)=3.5 \%$

This shows though $5 \%$ of cement is added, effective cement contain comes down to $3.5 \%$.

' $E$ ' is calculated from the slopes of normal Stress-Strain at the $30 \%$ of ultimate load [14 CRATerre].

' $E$ ' in linear range of $\sigma-\varepsilon$ is found from the slope between 33 and $5 \%$ of the stress in maximum [15 Hemant B. Kaushik, Sudhir K. Jain and Durgesh; 16 MSJC]. For non-linear, 66\% of the maximum is considered [17 Powell B., Hodgkinson H.R].

\section{MATERIAL TO CONFIRM}

\section{A. Cement}

Confirming to (Part 1) year 1991 of IS 1489 [18] Ordinary Portland Pozzalana Cement (Fly ash based) 53 grade is used in this work.

\section{B. Fine Aggregates}

Confirming to Indian standard aggregates IS 383-2002 [19], natural river sand of Zone-II from Tamil Nadu is used for this work.

\section{BLOCKS/BRICKS}

C. Block testing for Water absorption at one minute from initial time

Different types of CSEB are studied 1. size 240 × 120 x 90 mm from Auroville Earth Institute, Auroville, Tamil Nadu, 2. Sri Aurobindo Society- Sharanam, Perumbur, Tamil Nadu.

Moister that block absorbs at initial rate is called as Initial Rate of Absorption (IRA). Tests are processed as per C 67-00 (2001C) of ASTM [20]. IRA is defined as Weight of the sample dipped in $3 \mathrm{~mm}$ height of water for $1 \mathrm{~min}\left(\mathrm{~W}_{2}\right)$ minus the dry weight of brick $\left(\mathrm{W}_{1}\right)$ per unit area of the sample $(\mathrm{A})$

$$
\operatorname{IRA}(\mathbf{k g} / \mathbf{m} 2 / \mathbf{m i n})=\left(\mathrm{W}_{2^{-}}-\mathrm{W}_{1}\right) / \mathrm{A}
$$

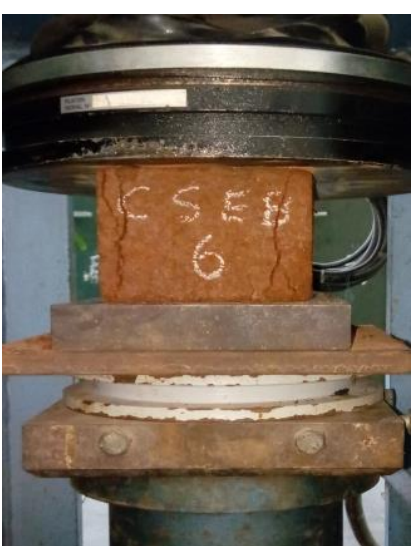

Fig 1. CSEB saturated blocks tested in CTM

Table 1. Observations found for CSEB Blocks

\begin{tabular}{|c|c|c|c|c|c|}
\hline \multirow{2}{*}{ Sr. No. } & Brick & $\begin{array}{c}\boldsymbol{f}_{b} \\
\text { type } \\
\text { Wet }\end{array}$ & $\begin{array}{c}\text { IRA } \\
(\mathbf{k g} / \mathbf{m} \mathbf{2} / \mathbf{m i n})\end{array}$ & $\mathbf{W A}$ & $\begin{array}{c}\boldsymbol{\rho}, \\
\text { Density } \\
(\mathbf{\%})\end{array}$ \\
\hline \multirow{2}{*}{1} & CSEB & 9.58 & 1.35 & 12 & 1963.57 \\
& Type I & {$[0.14]$} & {$[0.34]$} & {$[0.11]$} & {$[0.054]$} \\
\hline \multirow{2}{*}{2} & CSEB & 8.28 & 1.17 & 9.13 & 1963.58 \\
& Type II & {$[0.3]$} & {$[0.39]$} & {$[0.2]$} & {$[0.06]$} \\
\hline
\end{tabular}

\section{Water Absorbed (WA)}

Water absorbed by block dipped in water in $24 \mathrm{hrs}$. is noted according to IS 3495- Part2 (1992b) [21]. In Table 1, it is observed IRA is $1.35 \mathrm{~kg} / \mathrm{m}^{2} / \mathrm{min}$ and WA is $12 \%$. Fig. 1 depicts wet blocks tested in saturated state in a CTM. Vertical cracks appear at the two extreme vertical ends. Formula for WA is given by the

$$
\mathrm{W}=100 \times\left(\mathrm{M}_{2}-\mathrm{M}_{1}\right) / \mathrm{M}_{1}
$$

Where $\mathrm{W}=$ water absorption in $\%, \mathrm{M}_{1}=$ Dry weight of the block; $\mathrm{M}_{2}=$ wet weight of the block.

\section{E. Test for Compression Strength}

These two types of CSEB are tested for $f_{b}$ in CTM, as per IS 1905 [22]. Six samples of each are tested for compression test.

\section{F. Cement Mortar}

Samples of CM 1:3, 1:5 are casted from PPC and sand of fine aggregates of zone II vide specification number IS 2250 (1995) [23]. $70.7 \mathrm{~mm}$ cement mortar cubes are absorbed in water for 28 days and tested in CTM. Fig. 2 gives the analysis by regression of the experimental data of mortars CM 1:3 and CM 1:5 tested in CTM. It is noticed that stress - strain relation of Cement mortar is linear.

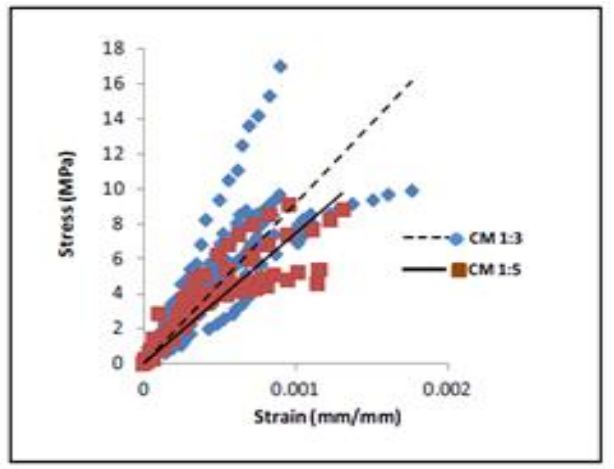

Fig. 2 Regression Analysis of the Experimental data of Cylinder Motor ---CM 1:3 E= 8279.5 MPa, $\mathrm{R}^{2}=0.63 ; \mathrm{CM} 1: 5$ $\mathrm{E}=6125.8 \mathrm{MPa}, \mathrm{R}^{2}: 0.74$ 


\section{MASONRY BRICK PRISM}

\section{A. Casting of Brick Prism}

With CM 1:3, 1:5 prisms are casted following Indian Standard No. 1905 [22]. H/b ratio is within 3.3 to 3.5. For binding the blocks, $10 \mathrm{~mm}$ thick cement mortar is used. After the speculated 28 days tests are performed.

\section{B. Prism Testing}

As per IS code 3495(1992b) part 1[24], in uni-axial compressive load, prism is tested. Mortar cylinders are tested as per IS code 2250 (1995) [23]. Tests are performed in stress controlled loading machine guided by liquid pressure up to $300 \mathrm{kN}$ jack. Demac gauges and LVDTs are used.

Fig.3a and Fig $3 \mathrm{~b}$ shows the actual and schematic setup of masonry prism. In a load cell, compression load is applied and registered in the Data logger. The compressive load is controlled manually through a Hydraulic pumping unit up to an accuracy level of $0.1 \mathrm{KN}$. The corresponding strains are measured with the help of a Demac gauge and LVDT.

\section{A. Methodology to find " $E$ "}

Three methodologies are adopted to find $\mathrm{E}: E_{t a n}, E_{\text {sec }} / E$ and $\mathrm{E}_{\text {sec } 2} / E_{N L}$.

\section{OBSERVATION AND OUTCOME}

\section{A. $\sigma-\varepsilon$ Curves for Block Masonry with dry joints}

CSEB with six samples of each are tested [as per IS specification No: 3495 (Part 1) 1992 [24].The average $\boldsymbol{\sigma}-\boldsymbol{\varepsilon}$ curves obtained are shown in the Fig $3 \mathrm{c}$. For CSEBDJ: $f_{b}$ is 9.587 [0.07] $\mathrm{MPa}, E_{b}: 1550.6$ [0.73] and $\mu: 0.242$ [0.11].

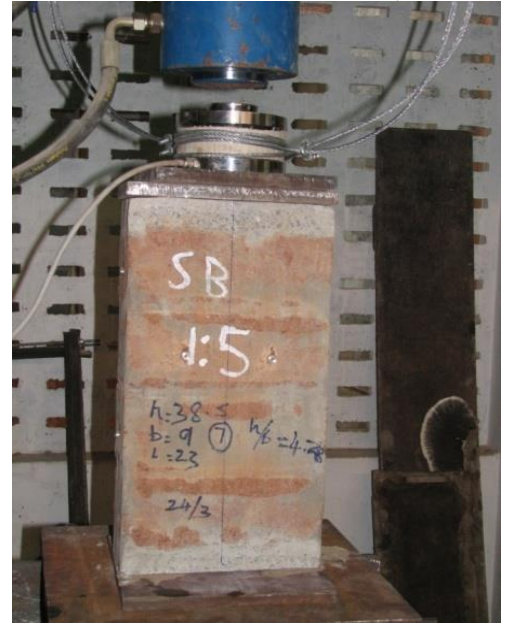

Figure. 3a Actual and schematic test setup

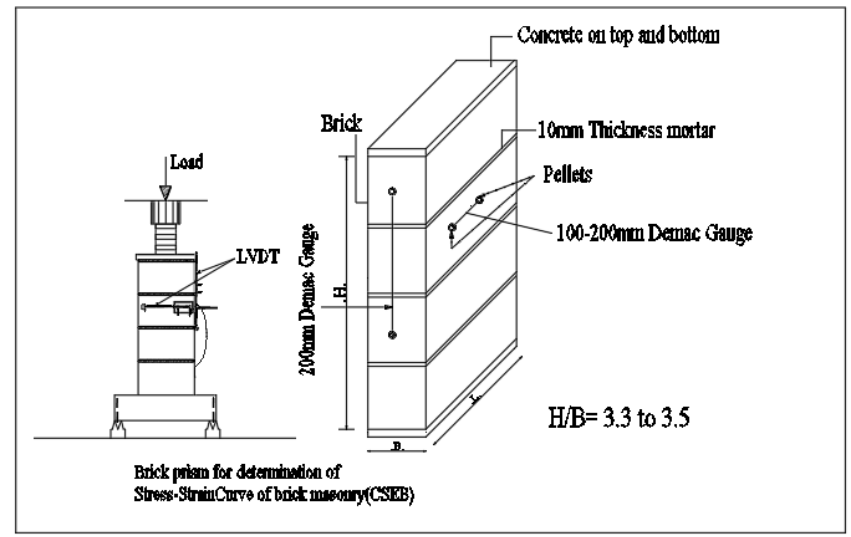

Figure. 3b Schematic test setup 1. 300 KN Loading Frame, 2.
Hydraulic Jack 3. Load cell of capacity $300 \mathrm{KN}$ 4. Block Prism 5. Demac Gauge 6. Pellets 7. Load cell cable 8. Data logger, 9. Data acquisition system 10. Cable to Hydraulic pumping unit, 11. Hydraulic pumping unit 12. LVDT

\section{B. Cement Mortar Prism Testing}

Cement: sand mortar with ratio of 1:3 stronger and 1:5 weaker are casted in $70.7 \mathrm{~mm}$ cube. Samples were tested and accordingly curves are obtained. Fig. 4a, 4b are drawn with 7 samples of 1:5 mortar and 9 samples of 1:3 mortar. $f_{b}$ of mortar depends on water-cement ratio and cement content. $\mathrm{E}$ and $\mu$ of cement mortars are mentioned in Table 2 .

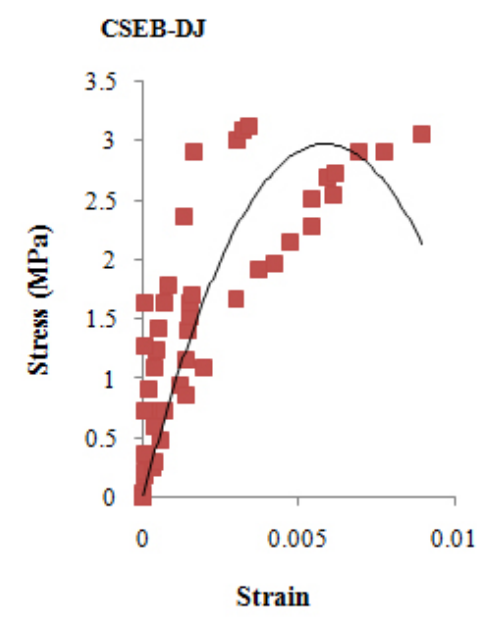

Fig. 3c Stress- Strain Curve CSEB-DJ

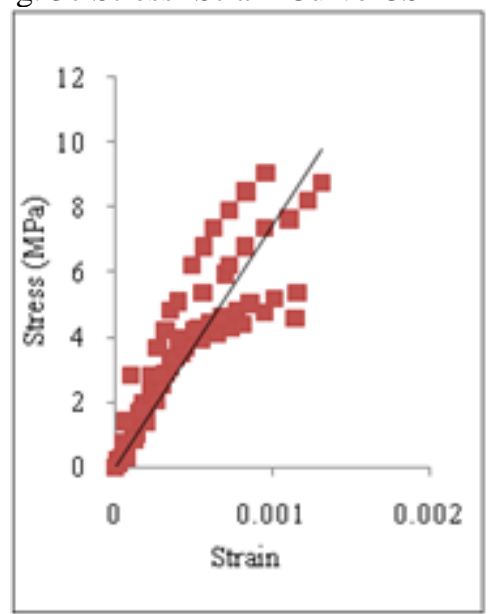

Fig. 4a $\sigma-\varepsilon$ in compression for CM 1:5 (40\% of UTS); $E_{b}=6125.8 \mathrm{MPa} ; R^{2}=0.74$.

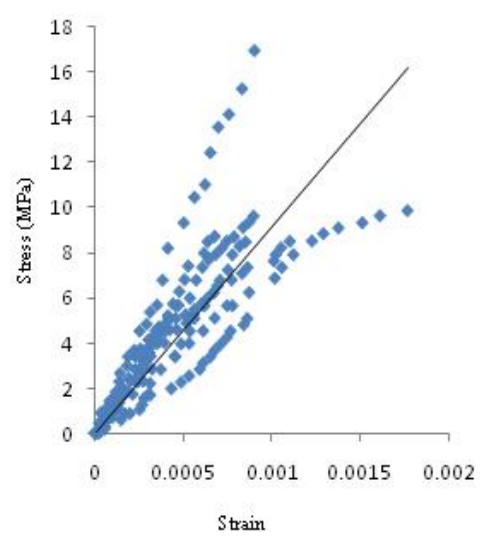

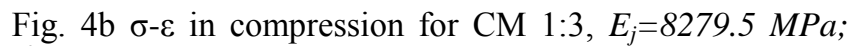
$R^{2}=0.63$. 


\section{Masonry Prism $\sigma-\varepsilon$ Curves}

Mortar consisting of cement : Sand as 1:3 and the other 1:5 are used as joints for the prisms. Blocks embedded with $10 \mathrm{~mm}$ mortar in each of the block makes the test specimen which gives the height of $330 \mathrm{~mm}$ to $350 \mathrm{~mm}$.

6 samples of each are taken and tested in the loading frame Fig. 5. Compression test of prisms are done according to IS

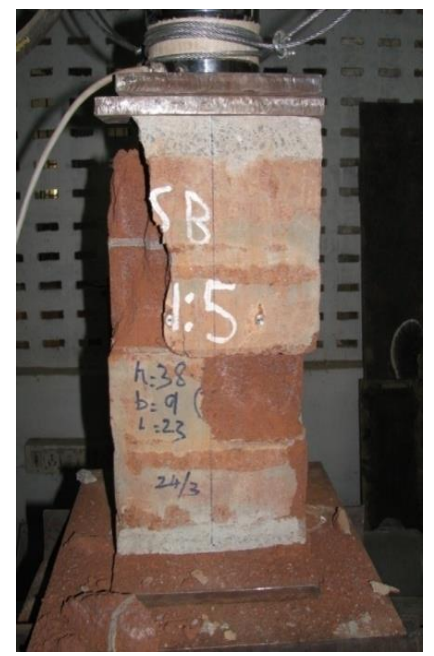

Fig. 5 Typical failure of CSEB masonry Prism, CM 1:5 in loading frame

Table 2. Elastic Property of Cement mortar (as per NBC Part-6 Section 4, 2016)

\begin{tabular}{|l|c|}
\hline $\begin{array}{l}\text { Type of } \\
\text { Mortar }\end{array}$ & $\begin{array}{l}\text { Compressive Strength of cube } \mathbf{( 7 0 . 7} \\
\mathbf{m m} \times \mathbf{7 0 . 7} \mathbf{~ m m} \times \mathbf{7 0 . 7} \mathbf{~ m m} \text { cube) } \mathbf{M P a}\end{array}$ \\
\hline $1: 03$ & 16.04 \\
& {$[0.19]$} \\
\hline $1: 05$ & 12.24 \\
& {$[0.12]$} \\
\hline
\end{tabular}

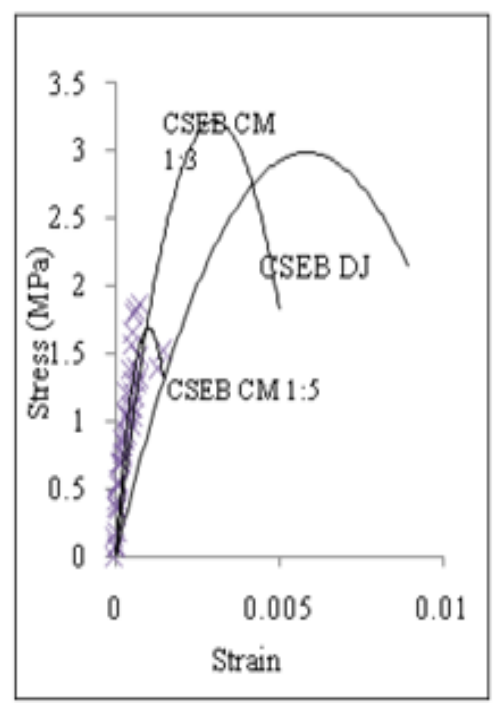

Fig.5a $\sigma-\varepsilon$ curve CSEB-CM 1:3 E: $2850 \mathrm{MPa} ; \mathrm{R}^{2}$ : 0.89 .

1905 -1987 [22]. Fig. 5 clearly shows the failure of CSEB \ with CM 1:5 masonry prism. Vertical cracks are visible. Three curves are drawn, shown in fig. 5a, 5b and 5c. CSEB of various types are computed and compared in Table 3 . It indicates that the failures are due to the cracks forming in the $90^{\circ}$ to the base. Of all the testing, it shows that $12 \%$ specimens

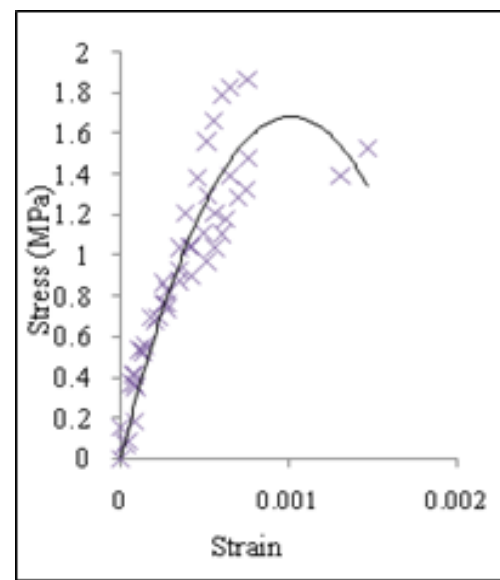

Fig. 5b $\sigma-\varepsilon$ curve CSEB-DJ (E:1550.6 MPa; $\left.R^{2}: 0.61\right)$, CSEB CM 1:3 (E: $\left.2850 M P a ; R^{2}: 0.89\right)$, CSEB CM 1:5 (E: 2323.33 MPa; $\left.R^{2}: 0.58\right)$

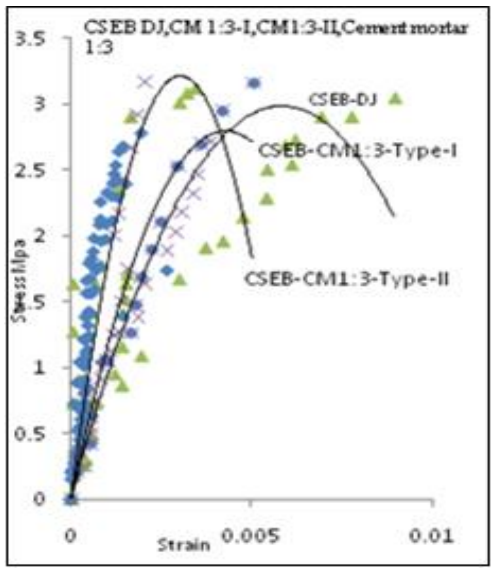

Fig.5c $\sigma-\varepsilon$ curve CSEB-DJ, CSEB CM 1:3 TypeI and CSEB CM 1:3 Type II .

Table 3 Comparison of Various CSEB Masonry

\begin{tabular}{|c|c|c|c|}
\hline $\begin{array}{c}\text { Type of } \\
\text { Masonry }\end{array}$ & $\begin{array}{c}\boldsymbol{U L T} \\
f_{\boldsymbol{b}}(\mathrm{MPa})\end{array}$ & $\begin{array}{c}\boldsymbol{E}_{\boldsymbol{m}} \\
(\mathrm{MPa})\end{array}$ & $\boldsymbol{E}_{\boldsymbol{M}} / \boldsymbol{E}_{\boldsymbol{b D}-\boldsymbol{j}}$ \\
\hline CSEB-DJ & 2.51 & 1550.6 & 1.00 \\
\hline CSEB 1:3-Type I & 3.02 & 1295.33 & 0.84 \\
\hline CSEB 1:5-Type I & 1.31 & 972.33 & 0.63 \\
\hline CSEB 1:3-TypeII & 2.44 & 2850 & 1.83 \\
\hline CSEB 1:5-TypeII & 1.62 & 2323.3 & 1.50 \\
\hline
\end{tabular}

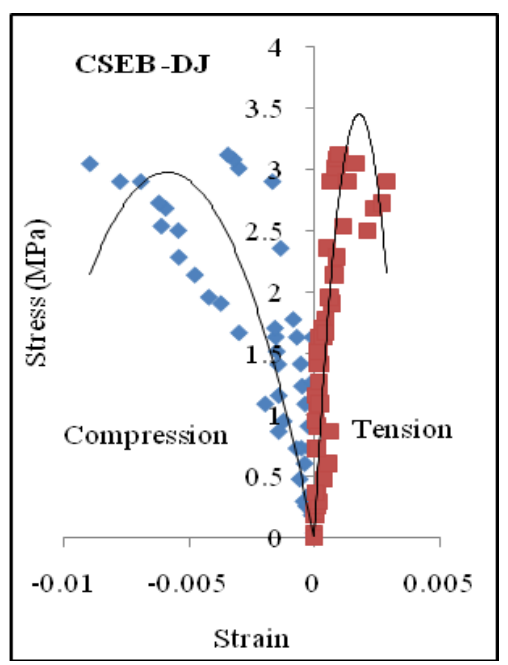

Fig. 6a Stress-Strain Diagram 1. CSEB DJ Comp. E: 1550.6 $\mathrm{MPa}, \mathrm{R}^{2}: 0.61 .2$. Ten E: $3869 \mathrm{MPa}, \mathrm{R}^{2}: 0.689$ 


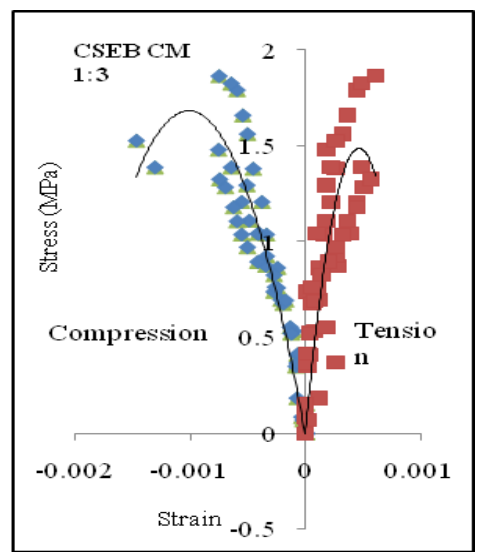

Fig. 6b Stress-Strain Diagram 1. CSEB CM 1:3 Comp. E: $2850 \mathrm{MPa}, \mathrm{R}^{2}: 0.89$ 2. Ten E: $6486 \mathrm{MPa}, \mathrm{R}^{2}: 0.659$

fail by crushing.

\section{Methodology to find $\mu$}

To find $\mu$ (Possion's Ratio), in Fig. (6a) and Fig. (6b) from $5 \%$ to $33 \%$ of UL stress a chord is drawn.

$$
\mu=\varepsilon_{\text {lat }}: \varepsilon_{\text {long }}
$$

\section{E. Brick Masonry}

In Fig. 7, Bar chart shows Modulus of Elasticity $E_{t a n}, E$ and $E_{66 \%}$ of various blocks.

$E_{\text {tan }}$ has the highest value and $E_{66}$ has the least value. $E$ indicates $E$ linear value and $E_{66 \%}$ indicates $E$ of nonlinear value. These values will help in the analytical design.

Fig. 8 gives the Poisson's ratio $\mu$ of various CSEB blocks. The prism strength $f^{\prime}{ }_{m}$, Modulus of Elasticity $E_{t}, E, E_{N L}$, Poisson's Ratio $\mu$ are tabulated in Table 4.

Table 4 Elastic property of the brick masonry

\begin{tabular}{|c|c|c|c|c|c|c|c|c|c|}
\hline $\begin{array}{l}\text { Type } \\
\text { of brick }\end{array}$ & $\begin{array}{c}\text { IRA } \\
(\mathrm{kg} / \mathrm{m} 2 / \mathrm{m} \\
\text { in })\end{array}$ & WA $(\%)$ & Comp. stress $\mathrm{N} / \mathrm{mm}^{2}$ & Mortar & $\begin{array}{l}\text { Ultimate strength } \\
\text { (MPa) of brick } \\
\text { prism }\end{array}$ & $\begin{array}{c}\mathrm{E}_{\text {tan }} \text { from graph } \\
\mathrm{MPa}\end{array}$ & $\begin{array}{c}\mathrm{E}_{\mathrm{sec}}(\mathrm{MPa}) \\
5-33 \%\end{array}$ & $\begin{array}{c}\mathrm{E}_{\mathrm{sec}}(\mathrm{MPa}) \\
66 \%\end{array}$ & $\underset{5-33 \%}{\mu}$ \\
\hline \multirow{3}{*}{$\begin{array}{l}\text { CSEB } \\
\text { Type I }\end{array}$} & \multirow{3}{*}{$\begin{array}{c}1.35 \\
{[0.34]}\end{array}$} & \multirow{3}{*}{$\begin{array}{c}0.12 \\
{[0.10]}\end{array}$} & \multirow{3}{*}{$\begin{array}{l}9.587 \\
{[0.07]}\end{array}$} & Dry Joint-I & $\begin{array}{c}2.51 \\
{[0.25]}\end{array}$ & $\begin{array}{c}1717.06 \\
{[0.74]}\end{array}$ & $\begin{array}{l}1550.6 \\
{[0.75]}\end{array}$ & $\begin{array}{l}1517.0 \\
{[0.76]}\end{array}$ & $\begin{array}{l}0.242 \\
{[0.11]}\end{array}$ \\
\hline & & & & $\begin{array}{l}1: 3- \\
\text { Type I }\end{array}$ & $\begin{array}{c}3.01 \\
{[0.33]}\end{array}$ & $\begin{array}{c}1450.67 \\
{[0.06]}\end{array}$ & $\begin{array}{c}1295.33 \\
{[0.05]}\end{array}$ & $\begin{array}{c}1176 \\
{[0.09]}\end{array}$ & $\begin{array}{c}0.15 \\
{[0.05]}\end{array}$ \\
\hline & & & & $\begin{array}{c}1: 5- \\
\text { Type I }\end{array}$ & $\begin{array}{c}1.31 \\
{[0.07]}\end{array}$ & $\begin{array}{l}1050.3 \\
{[0.119]}\end{array}$ & $\begin{array}{l}972.33 \\
{[0.13]}\end{array}$ & $\begin{array}{l}925.33 \\
{[0.123]}\end{array}$ & $\begin{array}{c}0.15 \\
{[0.05]}\end{array}$ \\
\hline \multirow{2}{*}{$\begin{array}{l}\text { CSEB } \\
\text { Type II }\end{array}$} & \multirow{2}{*}{$\begin{array}{c}1.17 \\
{[0.39]}\end{array}$} & \multirow{2}{*}{$\begin{array}{c}9.1 \\
{[0.2]}\end{array}$} & \multirow{2}{*}{$\begin{array}{l}8.28 \\
{[0.3]}\end{array}$} & $\begin{array}{c}1: 3- \\
\text { Type II }\end{array}$ & $\begin{array}{c}2.44 \\
{[0.17]}\end{array}$ & $\begin{array}{c}3029.60 \\
{[0.32]}\end{array}$ & $\begin{array}{c}2850 \\
{[0.33]}\end{array}$ & $\begin{array}{c}2738 \\
{[0.34]}\end{array}$ & $\begin{array}{c}0.16 \\
{[0.11]}\end{array}$ \\
\hline & & & & $\begin{array}{c}1: 5 \\
\text { Type-II }\end{array}$ & $\begin{array}{c}1.62 \\
{[0.18]}\end{array}$ & $\begin{array}{c}2557.33 \\
{[0.38]}\end{array}$ & $\begin{array}{c}2323.33 \\
{[0.37]}\end{array}$ & $\begin{array}{c}2263.33[0.38 \\
]\end{array}$ & $\begin{array}{c}0.22 \\
{[0.18]}\end{array}$ \\
\hline \multirow{2}{*}{$\begin{array}{c}\text { Cement } \\
\text { mortar }\end{array}$} & - & - & $\begin{array}{l}16.04 \\
{[0.19]}\end{array}$ & $1: 3$ & $\begin{array}{c}8.46 \\
{[0.39]}\end{array}$ & $\begin{array}{c}10572.6 \\
{[0.32]}\end{array}$ & $\begin{array}{l}8279.5 \\
{[0.29]}\end{array}$ & $\begin{array}{l}7480.7 \\
{[0.33]}\end{array}$ & $\begin{array}{c}0.18 \\
{[0.12]}\end{array}$ \\
\hline & & & $\begin{array}{c}12.24 \\
{[0.12]}\end{array}$ & $1: 5$ & $\begin{array}{c}5.69 \\
{[0.25]}\end{array}$ & $\begin{array}{l}7599.5 \\
{[0.27]}\end{array}$ & $\begin{array}{l}6125.8 \\
{[0.26]}\end{array}$ & $\begin{array}{l}5834.7 \\
{[0.31]}\end{array}$ & $\begin{array}{c}0.19 \\
{[0.13]}\end{array}$ \\
\hline
\end{tabular}

\section{F. Discussion}

1) From experiments carried out, the range of compressive strength $f_{j}$ of Cement Mortar 1:3 and 1:5 are 12.72 to 22.44 and 10.76 to $14.52 \mathrm{MPa}$ respectively. $E_{\text {sec } 40 \%}$ of CM 1:3 varies between 3815 to $13290 \mathrm{MPa}$ and that of 1:5 is 4389 to $7864 \mathrm{MPa}$. The ratio of $E_{\text {sec } 40 \%} \mathrm{CM} 1: 5$ to $1: 3$ is around $60 \%$. The increase in $E_{\text {sec } 40 \%}$ is not proportionate to the increase in $f_{b}$. Poisson's Ratio for CM 1:3 is between 0.15 and 0.20 and that of $1: 5$ is 0.16 to

0.23 .

2) From the experimental results, it is observed that the ratio of $f^{\prime}{ }_{m}$ of CSEB 1:3 to CM 1:3 is in range $28 \%-35 \%$ and that of CM 1:5 varies $22-28 \%$. Similarly, $E$ value of CSEB-DJ, 1:3 and 1:5 is 510-3410, 1050- 3670 and 1400-3518 MPa respectively.

3) It is observed that compressive strength increases with the increase of the density of the block

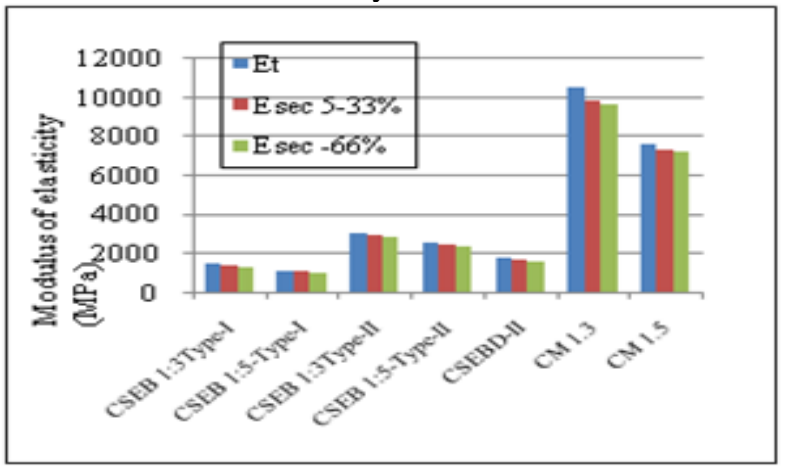

Fig. $7 \mathrm{E}_{\mathrm{t}}, \mathrm{E}_{\mathrm{sec} 1}$ and $\mathrm{E}_{\mathrm{sec} 2-66 \%}$ of various types of CSEB blocks

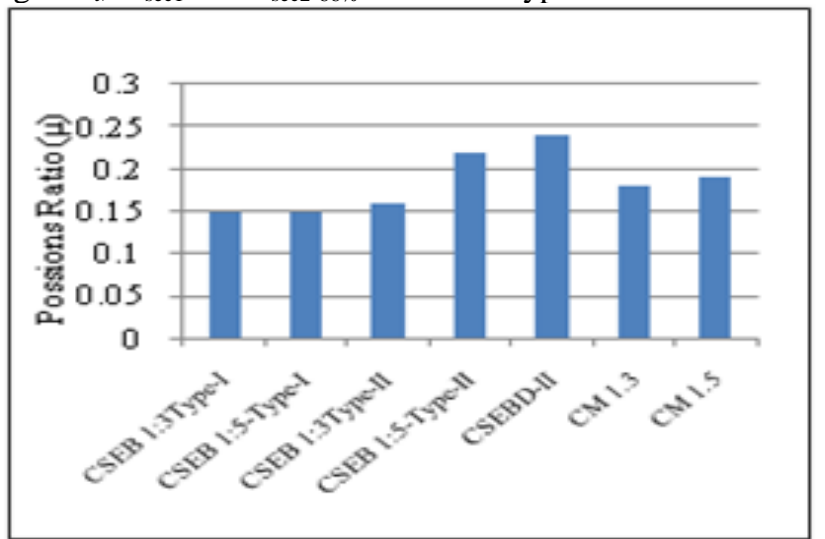

Fig. 8 Poisson's ratio of various types of blocks 
$\mathrm{MPa}$ and that of 1:5 is 1400-3518 MPa. High compressive strength of CM does not increase proportionally with $\mathrm{f}_{m}{ }_{m}$ and $E_{\text {secl }}$.

4) It is observed that $\sigma-\varepsilon$ curves of brick masonry was below that of CSEB blocks.

5) Further research is required to find out the bond, shear strength and effects when lateral force is applied on block masonry.

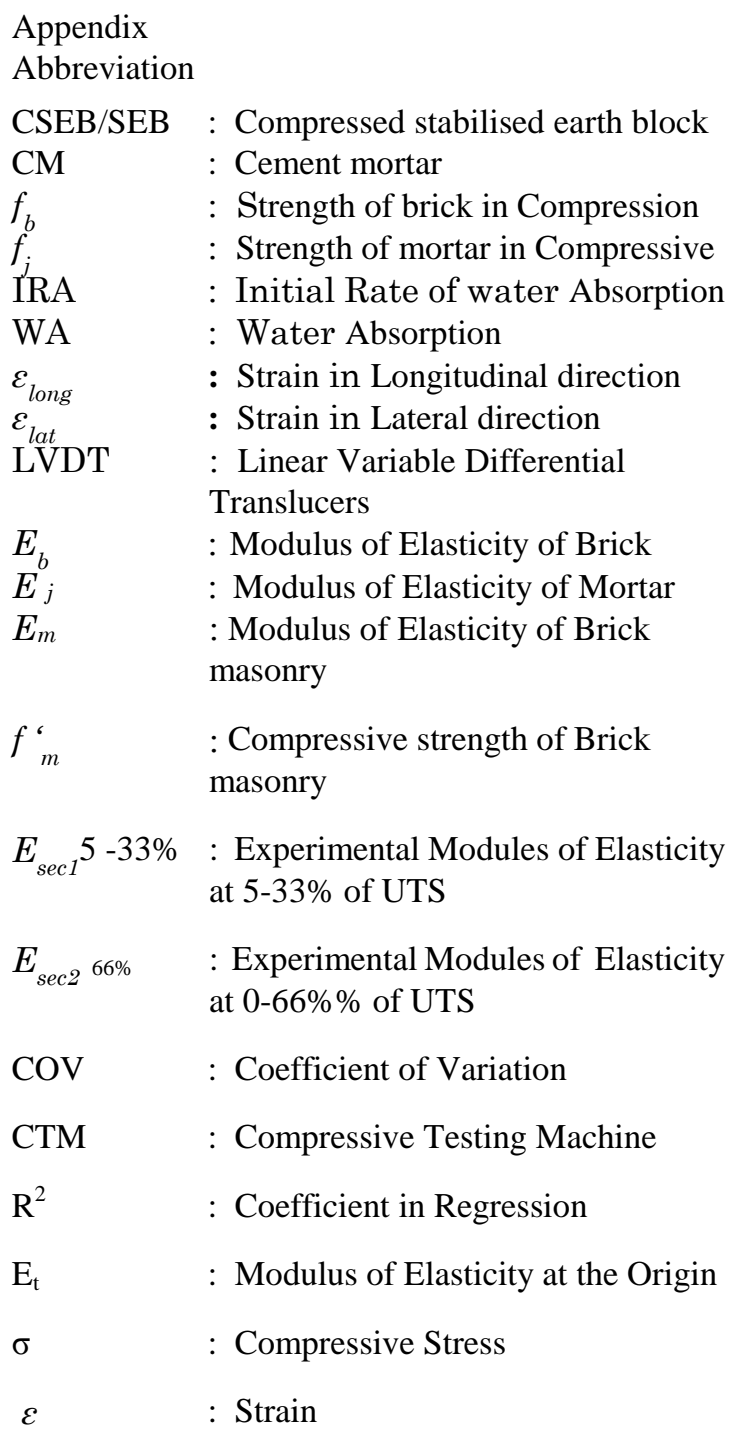

\section{REFERENCES}

[1] Fetra Riza Venny, Abdul Rehman and Ahmad Zaidi, "Preliminary study of Compressed Stabilized Earth Brick (CSEB)", Australian Journal of Basic and Applied Sciences, 5(9): 6-12, 2011. doi: 10.1109/CSSR.2010.5773936

[2] Satprem, Auroville Earth Institute, Tamil Nadu.

[3] Bachir Taallah and Abdelhamid Guettala, "The mechanical and physical properties of compressed earth blocks stabilized with lime and filled with untreated and alkali-treated date palm fibers", Construction and Building Materials, (2016) 52-62. doi: 10.1016/j.conbuildmat.2015.12.007

[4] Guettala, Houari, Mezghiche and Chebili, "Durability of Lime Stabilized Earth Blocks", Courrier du Savoir- $N^{\mathrm{o}} 2$, juin 2002, pp. 61-66. doi: 10.1680/scc.31777.0064

[5] Ziegler, Ling and Perry, "Effect of short polymer fibres on crack developmentin clays, soils", Found, 38 (1) (1998) 247-253. doi: 10.3208/sandf. 38.247

[6] Bahar R. Benazzoug M and Kenai. S, "Performance of compacted cement-stabilized soil", Cement and Concrete Composite , 27(7) pp 811-820 2004. doi: 10.1016/j.cemconcomp.2004.01.003
[7] G. E. Ntamack, T. Degho, T.Beda, Charif D’Ouazzane, "Determination of Mechanical Characteristics of Compressed and Stabilized Earth Blocks by Cement, by Mixture Cement and Sawdust, and by the Lime through the Elasticity-Damaging Coupling Model", Internation Journal of Sciense and Technology, Vol. 2, No.9, September 2012

[8] Walker P. and Stace T. "Properties of some cement stabilised compressed earth blocks and mortars" Materials and Structures/Mat4riaux et Constructions, Vol. 30, November 1997, pp $545-551$

[9] J E Oti, J M Kinuthia, and J Bai, "Engineering properties of unfired clay masonry bricks", Engineering Geology, 107(3-4) p 130-139, 2009. doi: 10.1016/j.enggeo.2009.05.002

[10] Walker P. : "Bond Characteristics of Earth Block Masonry" Journal of Materials in Civil Engineering, Vol. 11, No. 3, August, 1999

[11] Walker P. J.: "Strength, Durability and Shrinkage Characteristics of Cement Stabilised Soil Blocks" Cemenf \& Concrete Composites 17 (1995) 301-310 1995 Elsevier Science Limited.

[12] Nanjunda Roa, "Structural masonry: Properties and behavior", Structural Masonry Ksn Seminar, IISC, April, 1996.

[13] Heathcote Kevan, "Compressive strength of cement stabilized pressed earth blocks", Building Research and Information Volume 19 Number 2 1991. doi: $10.1080 / 09613219108727106$

[14] CRATerre, (1989), "Traité de construction en Terre ". Tomes I et II (Parenthèses, Marseille), 1989.

[15] Hemant B. Kaushik, Durgesh C. Rai and Sudhir K. Jain, "Uniaxial compressive stress-strain model for clay brick masonry", Current Science vol. 92, No. 4, Feb 2007

[16] Building Code requirement for Masonry Structures (ACI 530-02/ASCE 5-02/TMS 402-02) Reported by the Masonry Standards Joint Committee (MSJC).

[17] B. Powell and H. R. Hodgkinson, "The determination of stress-strain relationship of brickwork", 1976, The British ceramic research association, Stroke-on-Trent, Great Britain

[18] Portland Pozzolana Cement (Fly ash based) Specification IS 1489-1991 (Part 1).

[19] IS 383 (Reaffirmed 2002), Specification for Coarse and Fine Aggregate from Natural Sources for Concrete Bureau of Indian Standards, New Delhi, 1970.

[20] ASTM C 67-00 (2001C Standard test methods for sampling and testing and structural clay tiles.

[21] Indian Standards IS 3495 (1992b), Indian Standard methods of burnt clay building bricks-Part2. Determination of water absorption, 3rd Rev., Bureau of Indian Standards, New Delhi, India.

[22] Indian Standards IS 1905 (1987), Code of practice for structural use of unreinforced masonry, 3rd Rev., Bureau of Indian Standards New Delhi, India.

[23] Indian Standards IS 2250 (1995), Indian Standard code of practice for preparation and use of masonry mortars, 5th Rev. Bureau of Indian Standards, New Delhi, India.

[24] Indian Standards IS 3495, (1992a). Indian standard method of test of burn clay building bricks-Part 1: Determination of compressive strength IS 3495, 3rd REV., Bureau of Indian Standards, New Delhi, India. 